\title{
Effect of regular inhaled salbutamol on airway responsiveness and airway inflammation in rhinitic non-asthmatic subjects
}

\author{
David W Evans, Cheryl M Salome, Gregory G King, S Janet Rimmer, J Paul Seale, \\ Ann J Woolcock
}

\begin{abstract}
Background - Regular, inhaled $\beta_{2}$ agonists may increase airway responsiveness in asthmatic subjects. The mechanism is not known but may be via an increase in airway inflammation. A study was undertaken to examine the effect of regular inhaled salbutamol on airway responsiveness to methacholine and hypertonic saline, on the maximal response plateau to methacholine, and on inflammatory cells in induced sputum in rhinitic non-asthmatic subjects.

Methods - Thirty subjects with a baseline maximal response plateau of $>15 \%$ fall in forced expiratory volume in one second $\left(F E V_{1}\right)$ entered a randomised, placebo controlled, parallel trial consisting of two weeks run in, four weeks of treatment, and two weeks washout. Methacholine challenges were performed at the beginning of the run in period, before treatment, after treatment, and after washout. Hypertonic saline challenges were performed before and after treatment and induced sputum samples were collected for differential cell counting.
\end{abstract}

Results - There was no change in airway responsiveness, maximal response plateau to methacholine, or in induced sputum eosinophils or mast cells. The maximum fall in $\mathrm{FEV}_{1}$ after hypertonic saline increased in the salbutamol group (median change $6.0 \%$, interquartile range (IQR) 11.0) but did not change in the placebo group (median change $1.3 \%$, IQR 5.5). Conclusions - Regular inhaled salbutamol for four weeks increases airway responsiveness to hypertonic saline but does not alter airway responsiveness to methacholine or cells in induced sputum in nonasthmatic individuals with rhinitis. The relevance of these findings to asthmatic subjects has not been established.

(Thorax 1997;52:136-142)

Keywords: airway responsiveness, regular salbutamol, rhinitic non-asthmatic subjects, sputum cells.

Recent studies have suggested that regular $\beta$ agonist administration may increase airway responsiveness to histamine and methacholine in asthmatic subjects. ${ }^{1-3}$ The mechanism by which this occurs is not known, but one possibility may be via an increase in airway inflammation.
Persistent bronchodilatation induced by regular $\beta$ agonist administration may allow an increased allergen load to reach the airways. ${ }^{4}$ Alternatively, tachyphylaxis of $\beta$ receptors present on mast cells may reduce their stabilising effect and allow inflammatory mediator release in response to a lesser stimulus than is normally required. ${ }^{56}$

Methacholine and histamine act directly on airway smooth muscle to cause bronchoconstriction which is related to thickening of the airway wall, smooth muscle contraction, and lung elastic recoil. ${ }^{7}$ Hypertonic saline is believed to cause bronchoconstriction indirectly by the release of inflammatory mediators from airway mast cells and possibly airway nerves, ${ }^{8}$ and may therefore be a marker of inflammatory processes. Inhalation of hypertonic saline is also the basis of techniques which induce sputum for cytological examination. ${ }^{9}$

Although the sensitivity of the airways is a useful indicator of the degree of airway responsiveness, the maximal extent of airway narrowing has been recognised as an important measurement in recent years. Maximal airway narrowing can be assessed during bronchial challenge by increasing the dose of inhaled stimulus until the forced expiratory volume in one second $\left(\mathrm{FEV}_{1}\right)$ ceases to decrease in response to further provocation, producing a plateau. ${ }^{10}$ It has been suggested that the maximal response plateau may be an index of greater clinical relevance than airway sensitivity as it is a reflection of the potential severity of an exacerbation of asthma. ${ }^{11}$

The aim of this study was to determine if regular treatment with a $\beta$ agonist (salbutamol) increases airway sensitivity to direct and indirect stimuli, increases the maximal response plateau, and increases the degree of inflammation of the airways, as assessed by inflammatory cells and mediator concentration in induced sputum. Non-asthmatic subjects with rhinitis with mildly increased maximal response plateaux at baseline were selected to provide subjects with a mild abnormality of the airway that did not require treatment.

\section{Methods}

SUBJECTS

Subjects with symptoms of rhinitis who had not used $\beta$ agonist or corticosteroid medications in the previous 12 months were recruited by advertisement. At screening a medical history was taken and high dose methacholine chal- 
lenge and allergen skin prick testing were performed. Subjects were eligible for inclusion in the study if they had a baseline $\mathrm{FEV}_{1}$ of more than $80 \%$ of the predicted value and a maximal response plateau to methacholine of $\geq 15 \%$ fall in $\mathrm{FEV}_{1}$. Written informed consent was obtained from all subjects and the study was approved by the ethics committee of the Central Sydney Area Health Service.

Sample sizes were calculated to give the study $80 \%$ power at the $5 \%$ significance level to detect a difference between treatment groups in the change in the maximal response plateau to methacholine of $10 \%$ fall in $\mathrm{FEV}_{1}$. A previous study in this laboratory had shown that the within subject repeatability of the maximal response plateau was $8.7 \%$ fall in $\mathrm{FEV}_{1}$.

\section{STUDY DESIGN}

Eligible subjects were entered into a randomised, double blind, placebo controlled, parallel trial of eight weeks duration. Participants undertook a run in period of at least two weeks duration to establish the repeatability of the methacholine response. At the end of the run in period a high dose methacholine challenge and a hypertonic saline challenge were performed on consecutive days. Induced sputum samples were collected for sputum cytological testing during the hypertonic saline challenge. This was followed by a four week treatment period during which subjects took either $200 \mu \mathrm{g}$ salbutamol or matched placebo by metered dose inhaler, without a spacer device, four times daily (eight puffs/day). Subjects were tutored in the use of a metered dose inhaler and the adequacy of their technique was checked before and after treatment. Upon completion of the treatment period high dose methacholine and hypertonic saline challenges were repeated and sputum samples were again collected. The trial concluded with a two week washout period at the end of which a final high dose methacholine challenge was performed. At each assessment visit subjects were asked to complete a questionnaire to document respiratory and nasal symptoms. Each canister of aerosol (salbutamol or placebo) was weighed before and after the treatment period to assess compliance. All challenge tests were performed by one investigator (DWE) at approximately the same time of day ( \pm 2 hours) for each subject.

SKIN PRICK TESTING

Atopic status was assessed by skin prick test reactions to 14 common aeroallergens. ${ }^{12} \mathrm{His}-$ tamine and glycerol were used as positive and negative controls, respectively. After 15 minutes the weal size was recorded as the long axis and its perpendicular and the mean value was used in analyses. A reaction was regarded as positive if the weal size was $4 \mathrm{~mm}$ or greater. Subjects were considered atopic if they had a positive reaction to any of the allergens tested. No subject had taken antihistamine medications during the three days prior to skin prick testing.
LUNG FUNCTION MEASUREMENTS

Spirometric tests were performed on a Vitalograph dry spirometer (Vitalograph Co, Buckingham, UK). Each measurement was repeated until two curves were obtained in which the $\mathrm{FEV}_{1}$ and forced vital capacity (FVC) were reproducible to within $100 \mathrm{ml}$ and the higher of these two values was recorded.

HIGH DOSE METHACHOLINE CHALLENGE Methacholine chloride (ACIC Inc, Ontario, Canada) was administered using a DeVilbiss No. 646 nebuliser (DeVilbiss Co, Somerset, Pennsylvania, USA) regulated by a breath activated dosimeter (Rosenthal French, Baltimore, Maryland, USA) and attached to compressed oxygen at $138 \mathrm{kPa}$ pressure. The dosimeter was set to allow nebulisation for 0.6 seconds per inhalation which produced a mean (SE) output of $0.01(0.0011) \mathrm{ml}$ per inhalation. A control dose of $0.9 \%$ sterile saline was administered at the commencement of each challenge, followed by methacholine chloride in concentrations of 3, 6, 25, 50, 100 and $200 \mathrm{mg} /$ $\mathrm{ml}$. Five inhalations, from slightly below functional residual capacity to total lung capacity, were taken of each solution. An additional five inhalations were taken of the $6 \mathrm{mg} / \mathrm{ml}$ solution and an additional 10 inhalations were taken of the $200 \mathrm{mg} / \mathrm{ml}$ solution. This method delivered methacholine chloride in cumulative, approximately doubling, doses ranging from $0.15 \mu \mathrm{mol}$ to $199 \mu \mathrm{mol}$.

The $\mathrm{FEV}_{1}$ was measured 60 seconds after the final inhalation of each solution. FVC was recorded at baseline, after the control dose, when a $20 \%$ reduction in $\mathrm{FEV}_{1}$ occurred, and after administration of the final dose. The procedure was terminated when a plateau had been established, when the highest dose had been administered, or when the $\mathrm{FEV}_{1}$ had fallen by $60 \%$ of the control $\mathrm{FEV}_{1}$ value. Inhaled salbutamol, $200 \mu \mathrm{g}$, was administered upon completion of the procedure. Subjects were required to cease salbutamol or placebo treatment at least six hours before methacholine challenge.

\section{HYPERTONIC SALINE CHALLENGE}

Challenges with hypertonic saline were undertaken on the day following methacholine challenge. A solution of $4.5 \%$ saline (Ajax Chemicals, Sydney, Australia) was administered via an Ultraneb 2000 ultrasonic nebuliser (DeVilbiss Co, Somerset, Pennsylvania, USA) for durations of 30 seconds, one minute, two minutes, four minutes, and two periods of eight minutes. ${ }^{8}$ The canister containing the saline solution was weighed before and after the challenge, and the rate of output of the nebuliser in $\mathrm{ml} / \mathrm{min}$ was determined. The test was stopped when the $\mathrm{FEV}_{1}$ fell by $20 \%$ from the baseline value or when the longest hypertonic saline exposure was completed. 
SPUTUM INDUCTION

Sputum was induced during the hypertonic saline challenge. Subjects were asked to produce sputum by forced coughing after the four and eight minute periods of inhaling hypertonic saline. In subjects who failed to produce sputum during the standard challenge an additional eight minute period of inhaled $4.5 \%$ saline was given after administration of $200 \mu \mathrm{g}$ of inhaled salbutamol.

DIFFERENTIAL CELL COUNT

At least four sputum plugs were selected from the sputum samples from each subject; the plugs were smeared onto glass slides and allowed to air dry. When possible, plugs were selected from sputum produced late in the procedure. All samples were smeared within two hours of production. Two slides from each subject were fixed in absolute methanol for 10 minutes, then stained in undiluted MayGrünwald stain for 10 minutes, briefly rinsed in tap water, and counterstained in Giemsa stain diluted 1:10 in Giemsa buffer ( $\mathrm{pH}$ 6.8). Two slides were also fixed in Carnoy's solution for 10 minutes, dehydrated in $70 \%$ alcohol for one minute, rinsed in tap water, and stained in $0.5 \%$ toluidine blue stain $(\mathrm{pH} 0.5)$ for 10 minutes.

Differential cell counts for neutrophils, macrophages, lymphocytes, bronchial epithelial cells, and eosinophils were performed on slides stained with May-Grunwald-Giemsa. The best slide from each subject at each saline challenge was selected and scanned on low power $(40 \times)$ for a region of at least 400 cells which were able to be counted continuously. Cells were counted on high power $(100 \times)$ across the whole width of the slide in a direction perpendicular to the direction of smearing until a total of 400 cells had been reached. Mast cell counts were performed on the slides stained with toluidine blue by the same procedure, except that a total of 1500 cells was counted.

Cell counting was performed blind to the subjects' identities. Results for each cell type were expressed as a percentage of the total cells counted. Intraobserver repeatability of differential cell counts was assessed by recounting 10 slides selected at random. Interobserver repeatability was assessed by a second reader counting the same 10 slides.

EOSINOPHIL CATIONIC PROTEIN ANALYSIS

To the remaining sputum sample an equal volume of $1 \%$ dithiotrietol was added. This was vortexed and placed in a shaking water bath for 30 minutes. The sample was then centrifuged at $700 \mathrm{~g}$ for five minutes at $4^{\circ} \mathrm{C}$ and the supernatant removed and stored at $20^{\circ} \mathrm{C}$ until eosinophil cationic protein (ECP) assay using an RIA-ECP kit (Pharmacia).

DATA ANALYSIS

Dose-response curves to methacholine and hypertonic saline were constructed by plotting the percentage fall in $\mathrm{FEV}_{1}$ from the control
$\mathrm{FEV}_{1}$ value against the log dose of methacholine or hypertonic saline. A maximal response plateau to methacholine was established when the decrease in $\mathrm{FEV}_{1}$ between two or more of the final doses was less than $5 \%$ of the control $\mathrm{FEV}_{1}$ value $^{13}$ and the level of the plateau was defined as the mean of the fall in $\mathrm{FEV}_{1}$ at these doses. By this definition of the plateau the maximal percentage fall in $\mathrm{FEV}_{1}$ to hypertonic saline was also calculated. Dose response ratios (DRRs) to methacholine and to hypertonic saline were calculated from the first point of the plateau as the percentage fall in $\mathrm{FEV}_{1}$ divided by the cumulative dose of methacholine or hypertonic saline. ${ }^{14}$

The maximal response plateau to methacholine, $\mathrm{FEV}_{1}, \mathrm{FVC}$, cytological, and ECP data are reported as arithmetic means with $95 \%$ confidence intervals ( $95 \% \mathrm{CI}$ ); dose response ratios to methacholine are reported as geometric means with $95 \%$ CIs and the change in DRR is reported in doubling dose units. ${ }^{14}$ Two tailed paired $t$ tests were used to analyse changes within a treatment group for these data, and two tailed unpaired $t$ tests were used to analyse changes between the two treatment groups. Maximal falls in $\mathrm{FEV}_{1}$ and DRR to hypertonic saline are reported as medians with interquartile ranges (IQR); the Wilcoxon ranked sign test was used to analyse changes within a treatment group, and the Mann-Whitney U test was used to analyse changes between treatment groups. The distribution of categorical data was analysed using Fisher's exact test. Correlations between data were examined by least square linear regression analysis. Significance for all tests was accepted at the $95 \%$ level. Repeatability of the maximal response plateau and the DRR to methacholine were analysed by the method of Peat et $a l,{ }^{14}$ and repeatability of cell counts was assessed with analysis of variance by calculation of the coefficient of reliability $(R) .{ }^{9}$

\section{Results}

SUBJECTS

Of the 60 volunteers screened for the study, 33 had mildly elevated maximal response plateaux to methacholine and were eligible to participate in the trial. Of these 33 subjects, one withdrew because of illness and one because of noncompliance. The data obtained from one subject were not included in the analysis because of poor repeatability of baseline spirometric values. The baseline characteristics of the salbutamol and placebo subject groups are shown in table 1 . All but four subjects were lifetime non-smokers, and none of the subjects had smoked for 10 years prior to the study. None had current symptoms of asthma or any significant chronic illness. All but two subjects completed the six assessment visits of the trial. Data from these two subjects have been included in the analysis, however, as they completed the post-treatment high dose methacholine challenge. Twelve subjects (five salbutamol, seven placebo) reported symptoms of respiratory tract infections during the trial, but there was no consistent effect of these episodes on any measurement. Seven subjects (four sal- 
Table 1 Baseline characteristics of subject groups at the initial screening visit

\begin{tabular}{|c|c|c|}
\hline & $\begin{array}{l}\text { Salbutamol } \\
(n=16)\end{array}$ & $\begin{array}{l}\text { Placebo } \\
(n=14)\end{array}$ \\
\hline$M: F$ & $6: 10$ & $4: 10$ \\
\hline Age (years) & $40.9(34.0$ to 47.9$)$ & $31.7(25.3$ to 38.2$)$ \\
\hline Height $(\mathrm{cm})$ & 169.5 (164.8 to 174.2$)$ & $171.5(167.3$ to 175.7$)$ \\
\hline Number atopic & 15 & 12 \\
\hline $\mathrm{FEV}_{1}(\%$ predicted $)$ & $104.9(98.2$ to 111.5$)$ & $105.6(95.8$ to 115.5$)$ \\
\hline $\begin{array}{l}\text { Methacholine DRR } \\
(\% \text { fall } \mathrm{FEV} / \mathrm{umol})\end{array}$ & $1.2(0.7$ to 2.2$)$ & 0.9 (0.3 to 1.6$)$ \\
\hline $\begin{array}{l}\text { Methacholine plateau } \\
\left(\% \text { fall } \mathrm{FEV}_{1}\right)\end{array}$ & $28.3(22.8$ to 33.8$)$ & $25.8(20.1$ to 31.5$)$ \\
\hline $\begin{array}{l}\text { Hypertonic saline DRR } \\
\left(\% \text { fall } \mathrm{FEV}_{1} / \mathrm{ml}\right)\end{array}$ & $0.24(0.60)$ & $0.08(0.14)$ \\
\hline $\begin{array}{l}\text { Hypertonic saline plateau } \\
\left(\% \text { fall } \mathrm{FEV}_{1}\right)\end{array}$ & $3.8(11.0)$ & $1.7(3.0)$ \\
\hline
\end{tabular}

$\mathrm{FEV}_{1}=$ forced expiratory volume in one second; $\mathrm{DRR}=$ dose-response ratio.

Values for age, height, $\mathrm{FEV}_{1}$ (\% predicted), and methacholine plateau are mean and $95 \%$ confidence intervals. Values for methacholine dose-response ratio (DRR) are geometric means and $95 \%$ confidence intervals. Values for hypertonic saline challenge, dose-response ratio and plateau are median and interquartile range.

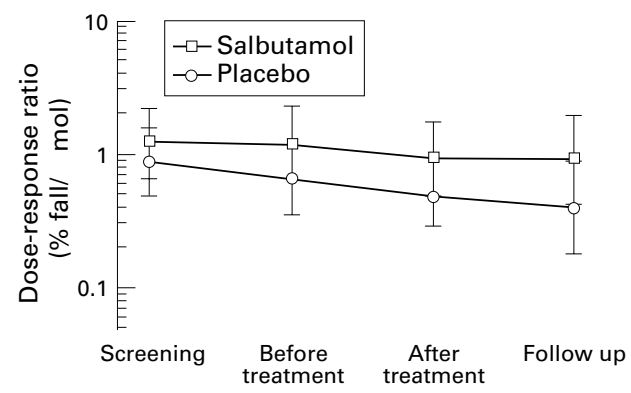

Figure 2 Dose-response ratio (geometric mean and 95\% confidence intervals) to methacholine in the salbutamol and placebo treatment groups at the two pretreatment challenge tests, after four weeks of treatment, and at follow up two weeks after the end of treatment.

DOSE RESPONSE RATIO TO METHACHOLINE

butamol, three placebo) reported past treatment with anti-asthma or present treatment with anti-rhinitis medication, but there was no consistent effect on any measurement.

Compliance with treatment was checked by weighing the canisters from the returned metered dose inhalers. The weight loss from the 28 canisters returned showed that 25 subjects took at least six inhalations per day, while three subjects took only five inhalations per day. These three subjects were all in the placebo group. Two subjects who failed to return their canisters gave a verbal assurance of compliance. Exclusion of the data from these five subjects did not alter the results of any statistical analysis.

MAXIMAL RESPONSE PLATEAU

There was no difference in mean baseline $\mathrm{FEV}_{1}$ or FVC values at any assessment. The repeatability of the maximal response plateau was $\pm 7.2 \%$ for the entire group and did not differ significantly between active $( \pm 7.5 \%)$ and placebo $( \pm 7.1 \%)$ groups. Treatment with salbutamol had no effect on the maximal response plateau to methacholine. Figure 1 shows mean values for the maximal response plateau at screening, before and after treatment, and at the follow up assessment. The mean change in the maximal response plateau before and after treatment was a fall of $3.1 \%(-1.8$ to 7.95$)$ in the salbutamol group and a fall of $0.6 \%(-3.61$ to 4.8 ) in the placebo group.

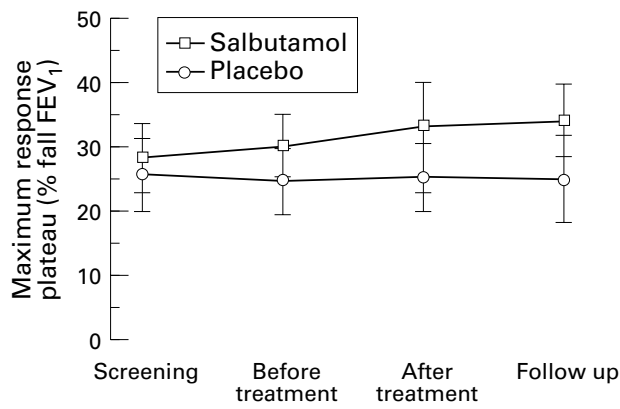

Figure 1 Maximal response plateau (mean and 95\% confidence intervals) to methacholine in the salbutamol and placebo treatment groups at the two pretreatment challenge tests, after four weeks of treatment, and at follow up two weeks after the end of treatment.
Treatment with salbutamol had no significant shows the mean DRRs of the active and placebo groups at the four high dose methacholine challenges completed during the study. The mean change in DRR before and after treatment was $0.79 \%$ fall $/ \mu \mathrm{mol}(0.42$ to 1.51$)$ in the salbutamol group and $0.66 \%$ fall $/ \mu \mathrm{mol}(0.37$ to $1.17)$ in the placebo group $(p=0.65)$. The repeatability of the DRR to methacholine at the two pretreatment measurements was \pm 2.1 doubling doses (DD) for the entire group and did not differ significantly between the active group $( \pm 2.4 \mathrm{DD})$ and placebo group $( \pm 2.0$ DD). There was a significant correlation between the DRR to methacholine and the maximal response plateau $(r=0.73, \mathrm{p}<0.001)$.

\section{HYPERTONIC SALINE CHALLENGE}

Figure 3 shows the individual changes in maximal percentage fall in $\mathrm{FEV}_{1}$ to hypertonic saline in the active and placebo groups. All but two subjects had a plateau on their dose response curve to saline. The treatment groups differed significantly both in median change in $6.0 \%$ (IQR 11.0), placebo 1.3 (5.5)\%, p= 0.04 ) and change in DRR (salbutamol $0.45 \%$ / $\mathrm{ml}$ (IQR 1.04), placebo $0.11(0.29) \% / \mathrm{ml}, \mathrm{p}=$ $0.03)$. In the active group the maximum percentage fall in $\mathrm{FEV}_{1}$ increased from a median

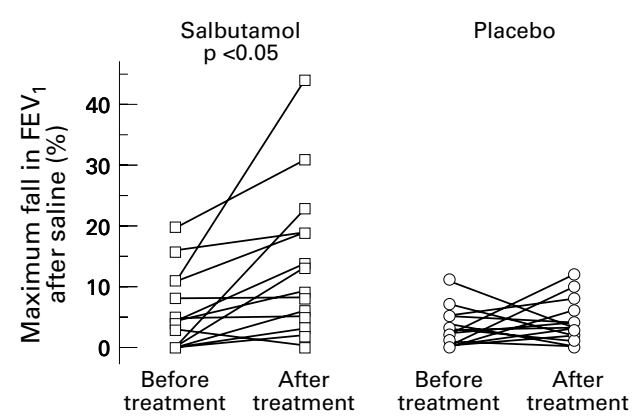

Figure 3 Maximum percentage fall in forced expiratory volume in one second $\left(F E V_{1}\right)$ during challenge with hypertonic saline before and after four weeks of treatment with either salbutamol or placebo. effect on the DRR to methacholine. Figure 2 maximum percentage fall in $\mathrm{FEV}_{1}$ (salbutamol 
Table 2 Mean (95\% confidence interval) sputum differential cell counts before and after treatment with salbutamol as a percentage of total cells counted

\begin{tabular}{lcc}
\hline & Before treatment & After treatment \\
\hline Salbutamol group & & \\
$\quad$ Bronchial epithelial cells & $5.1(0$ to 10.5$)$ & $8.6(0.3$ to 16.9$)$ \\
Macrophages & $44.8(33.0$ to 56.5$)$ & $47.4(34.9$ to 59.9$)$ \\
Neutrophils & $43.0(29.0$ to 56.9$)$ & $37.1(18.9$ to 55.3$)$ \\
Lymphocytes & $3.0(2.0$ to 3.9$)$ & $3.4(2.0$ to 4.7$)$ \\
Eosinophils & $4.4(0$ to 10.2$)$ & $3.7(0.3$ to 7.1$)$ \\
$\quad$ Mast cells & $0.09(0$ to 0.17$)$ & $0.22(0$ to 0.5$)$ \\
Placebo group & & \\
Bronchial epithelial cells & $6.3(0$ to 14.3$)$ & $2.7(1.1$ to 4.2$)$ \\
Macrophages & $48.0(37.8$ to 58.2$)$ & $57.9(47.5$ to 68.3$)$ \\
Neutrophils & $41.0(29.2$ to 52.9$)$ & $33.3(22.8$ to 43.8$)$ \\
Lymphocytes & $2.6(1.9$ to 3.3$)$ & $3.4(2.1$ to 4.8$)$ \\
Eosinophils & $2.2(0.5$ to 3.8$)$ & $2.8(0$ to 6.9$)$ \\
Mast cells & $0.16(0$ to 0.4$)$ & $0.13(0$ to 0.4$)$ \\
\hline
\end{tabular}

(IQR) of $3.8 \%$ (11.0) before treatment to $10.7 \%$ (14.6) after treatment $(\mathrm{p}<0.01)$, and the median DRR (IQR) increased from $0.24 \% /$ $\mathrm{ml}(0.60)$ before treatment to $0.68 \% / \mathrm{ml}(0.65)$ after treatment $(\mathrm{p}<0.01)$. In the control group there was no change in the maximum percentage fall in $\mathrm{FEV}_{1}$ with a median (IQR) of $1.7 \%$ (3.0) before treatment and 3.0\% (4.0) after treatment $(\mathrm{p}=0.29)$, or in the DRR with a median (IQR) of $0.08 \%$ fall $/ \mathrm{ml}(0.14)$ before treatment and $0.19 \%$ fall $/ \mathrm{ml}(0.15)$ after treatment $(\mathrm{p}=0.17)$.

\section{SPUTUM CYTOLOGY}

Twenty two subjects $(79 \%)$ were able to produce sputum during both saline challenges, and $24(85 \%)$ were able to produce sputum during at least one saline challenge. Only the data from the 22 subjects (11 in each group) who produced samples both before and after treatment were included in the analysis. For the entire subject group the mean differential eosinophil count at baseline was $3.3 \%$ of total cells counted (95\% CI 0.5 to 6.0 ) and the mean mast cell count was $0.12 \%$ (95\% CI 0.0 to 0.3 ). There was no significant difference in mean cell counts of the active and placebo groups either at baseline or after treatment (table 2). The mean change between the cell counts before and after treatment did not differ significantly between groups for either eosinophils (active -3.74 ( -9.8 to 2.5 ); placebo $-3.0(-6.3$ to 0.2$) ; \mathrm{p}=0.83)$ or mast cells (active $0.1(-0.1$ to 0.4$)$; placebo $-0.1(-0.2$ to 0.4$) ; \mathrm{p}=0.13)$. Exclusion of the non-atopic subjects did not alter the results. Intraobserver and interobserver repeatability of cell counts was very good (coefficient of reliability $>0.8$ ) or good (coefficient of reliability $0.61-0.8$ ) for all cell types, except for the intraobserver counts of lymphocytes which were moderately repeatable $(R=0.44)$.

There was no relationship at baseline or after treatment between differential sputum eosinophil or mast cell counts and the DRR or the maximal response plateau to methacholine, or the maximal percentage fall in $\mathrm{FEV}_{1}$ or DRR to hypertonic saline. The eosinophil and mast cell counts at baseline did not predict change in DRR or maximal percentage fall in $\mathrm{FEV}_{1}$ to hypertonic saline or methacholine after treatment, and there was no relationship between individual changes in eosinophil or mast cell count and individual changes in maximal response plateau or responsiveness to hypertonic saline.

ECP ANALYSIS

Eosinophil cationic protein was measured in paired sputum samples from the 14 subjects (eight in the salbutamol group and six in the placebo group) for whom sufficient sputum remained after four sputum plugs were removed for cell counting. There was no significant difference between the groups in the ECP levels before and after treatment or the mean change in ECP after the treatment period (active $-11.7 \mathrm{ng} / \mathrm{ml}$ ( -45.1 to 21.8 ); placebo $0.32 \mathrm{ng} / \mathrm{ml}(-9.8$ to 10.4$) ; \mathrm{p}=0.49)$. There was a tendency for sputum levels of ECP to fall in the salbutamol group $(30.4 \mathrm{ng} / \mathrm{ml}(95 \%$ CI 0.7 to 60.0 ) before treatment, $19.9 \mathrm{ng} / \mathrm{ml}$ (1.1 to 38.5$)$ after treatment), but this did not achieve statistical significance. There was no change in the sputum levels of ECP in the control group $(6.5 \mathrm{ng} / \mathrm{ml}(-3.1$ to 16.3$)$ before treatment, $6.9 \mathrm{ng} / \mathrm{ml}(4.0$ to 9.7$)$ after treatment).

\section{Discussion}

This study has shown that salbutamol, inhaled regularly for four weeks, did not increase airway sensitivity or maximal response plateau to methacholine in rhinitic non-asthmatic subjects with mildly increased maximal response plateaux. Salbutamol use was associated with a small but significant increase in airway responsiveness to hypertonic saline. There was no detectable change in inflammatory cells present in induced sputum.

Previous studies ${ }^{1-3}$ which have suggested that regular $\beta$ agonists cause an increase in airway hyperresponsiveness have only examined asthmatic subjects, so it is not clear whether such effects are peculiar to the asthmatic state. Nonasthmatic rhinitic subjects were recruited for this study for several reasons. Firstly, we wished to exclude subjects who were taking regular $\beta$ agonist medication to avoid any confounding effects of persistent $\beta$ receptor stimulation. Secondly, we wished to include subjects with a maximal response plateau to inhaled methacholine of more than $15 \%$ fall in $\mathrm{FEV}_{1}$. This criterion was based upon the results of an open trial, previously undertaken in our laboratory, which showed a significant increase in plateau after regular $\beta$ agonist use only in non-asthmatic subjects with a baseline plateau of more than $15 \%$. Many subjects with rhinitis have mild airway hyperresponsiveness, ${ }^{15}$ and we expected that some of our patients would have an increased maximal response plateau; 55\% of screened subjects met the criterion of a maximal response plateau of more than $15 \%$. In asthmatic individuals it is not usually possible to measure a maximal response plateau during methacholine challenge. ${ }^{10}$ Thirdly, subjects with rhinitis are likely to be atopic. If $\beta$ agonists alter airway sensitivity by increasing the extent of allergic inflammation of the airways, as has been proposed, ${ }^{1}$ this change might be most 
evident in atopic individuals. Of the 30 subjects recruited in this study 29 had rhinitis and 27 were atopic.

At baseline the active group was slightly more responsive to methacholine and to hypertonic saline than the control group, although this difference was not significant. Four subjects had responses to methacholine in the hyperresponsive range (DRR $>5 \%$ fall in $\mathrm{FEV}_{1} / \mu \mathrm{mol}$ methacholine $)^{16}$ and two of them experienced a fall in $\mathrm{FEV}_{1}$ of more than $20 \%$ during the hypertonic saline challenge. A response of this magnitude is usually seen only in asthmatic individuals, ${ }^{8}$ although these subjects did not report symptoms of asthma and were not being treated for asthma. Despite double blind randomisation, two of the three non-atopic subjects (including the non-rhinitic subject) were assigned to the control group, and three of the four subjects with airway hyperresponsiveness (including the two subjects hyperresponsive to hypertonic saline) were assigned to the active group. Use of a crossover study design may have overcome this problem, but this approach was rejected because, at the time the study was planned, we were unable to determine the length of the washout period between treatments required to reverse any effect of $\beta$ agonists. Exclusion of the data from the hyperresponsive subjects did not substantially alter the results.

Regular inhaled salbutamol was associated with a small but significant increase in sensitivity and a maximal percentage fall in $\mathrm{FEV}_{1}$ to hypertonic saline but had no effect on sensitivity or the maximal response plateau to methacholine. While methacholine constricts airway smooth muscle directly, hypertonic saline acts indirectly via release of mediators from airway inflammatory cells. The results of this study suggest that regular salbutamol affects the indirect, but not the direct, component of airway responsiveness. However, regular salbutamol inhalation was not associated with a change in eosinophil numbers or ECP levels in the sputum, suggesting that eosinophils had no role in increasing responsiveness to hypertonic saline. An effect of $\beta$ agonists on ECP levels cannot be ruled out, however, since the wide confidence intervals suggest that the absence of significant changes may be a type II error. The number of mast cells did not increase but we have no index of mast cell activation.

There are several potential mechanisms by which regular use of $\beta$ agonist drugs could increase airway responsiveness, but most are not supported by the findings of the present study. The absence of any effect on the response to methacholine suggests that tachyphylaxis of airway smooth muscle $\beta$ receptors, which may reduce the ability of $\beta$ receptor stimulation to oppose bronchoconstriction, ${ }^{17}$ is not a likely mechanism. Small increases in airway wall thickening, which could be induced after $\beta$ agonist use by vasodilatation of the airway vasculature $^{18}$ or by an inflammatory cell infiltrate, might be expected to increase airway responsiveness to direct stimuli, ${ }^{7}$ and the absence of such changes suggests that this mechanism is also unlikely. The absence of any changes in numbers of inflammatory cells in induced sputum or in ECP levels is consistent with the view that regular $\beta$ agonist does not directly increase airway inflammation.

Two studies in asthmatic subjects have shown that regular salbutamol causes no change in mast cell numbers ${ }^{1920}$ in bronchial biopsy specimens, which is in accord with our finding in sputum of atopic non-asthmatic subjects. Manolitsas et $a l^{20}$ also showed that, after regular salbutamol, the change in the number of eosinophils in bronchial biopsy specimens both in total numbers and in the number of activated cells did not differ from that after placebo, nor was there any significant change in the concentration of ECP in bronchoalveolar lavage fluid.

An increase in mast cell activity is a possible explanation for the increased airway responsiveness to hypertonic saline, which is believed to induce bronchoconstriction by stimulating mast cell degranulation. ${ }^{8} \beta_{2}$ receptors are present on mast cells and exert a stabilising effect on these cells. ${ }^{21}$ It has been suggested that regular administration of a $\beta$ agonist may cause tachyphylaxis of $\beta$ receptors on mast cells, thereby reducing mast cell stabilisation. ${ }^{56}$ Tachyphylaxis of the $\beta$ receptor on human mast cells has not been proven; however, oral ${ }^{22}$ and inhaled ${ }^{23} \beta$ agonist administration causes tachyphylaxis of the $\beta$ receptor on circulating human leucocytes and, in animal models, agonist-induced tachyphylaxis of $\beta$ receptors on airway mast cells has been demonstrated. ${ }^{24}$ Recent studies of regular $\beta$ agonist use in asthmatic subjects have also suggested that increased mast cell activity, resulting from tachyphylaxis of the mast cell $\beta$ receptor, is responsible for an increase in airway responsiveness. ${ }^{6}$ Three studies have shown an increase in both the early and late asthmatic response to inhaled allergen following regular $\beta$ agonist use. ${ }^{6225}$ Another study reached a similar conclusion by comparing the bronchoprotective effect of terbutaline to challenge with methacholine and with AMP (a mast cell stimulus) after seven days of treatment with terbutaline. ${ }^{5}$ If tachyphylaxis of $\beta$ receptors modifies the release of mediators from mast cells, then the results of the present study, in which both the sensitivity and the level of the plateau to hypertonic saline increased, suggest that both the sensitivity of the mast cells to releasing stimuli and the total amount of mediators released may be affected.

It may not be appropriate to extrapolate this result directly from rhinitic non-asthmatic subjects to asthmatic subjects as the inflammatory processes of the airways in these two groups may be different. However, anecdotal evidence from two subjects suggested that the change in hypertonic saline responsiveness may be large in asthmatic individuals. Both these subjects had airway hyperresponsiveness to methacholine at screening and experienced a reduction in $\mathrm{FEV}_{1}$ of more than $20 \%$ at the pretreatment hypertonic saline challenge. Following treatment with salbutamol one of these subjects experienced a substantial increase in the maximal percentage 
fall to hypertonic saline; the other subject showed a large increase in both the maximal percentage fall to hypertonic saline and maximal response plateau to methacholine, and reported wheezing and breathlessness during the treatment period.

In summary, this study has shown that regular inhaled salbutamol increases airway responsiveness to inhaled hypertonic saline in non-asthmatic individuals. This change is consistent with an effect on mast cell activity, although the mechanism is not known.

The authors thank Ms Deanne Anson for her important contribution to this work in preparing the sputum samples for ECP analysis and performing the assay. We are also grateful to $\mathrm{Ms}$ Lorma Gutierrez and Dr Peter Gibson for their expert advice on the identification of cells in sputum.

1 Sears MR, Taylor DR, Print CG, Lack DC, Li O, Flannery EM, et al. Py EM, et al. Regular inhaled beta-agonist tre
chial asthma. Lancet 1990;336:1391-6.

2 Vathenen AS, Higgins BG, Knox AJ, Britton JR. Rebound increase in bronchial responsiveness after treatment with inhaled terbutaline. Lancet 1988;i:554-8.

3 Van Schayk C, Graafsma SJ, Visch MB, Dompeling E, Van Weel C, Van Herwaarden C. Increased bronchial hyperresponsiveness after inhaling salbutamol during one year is not caused by subsensitization to salbutamol. $\mathcal{F}$ Allergy Clin Immunol 1990;86:793-800.

4 Lai CKW, Twentyman OP, Holgate ST. The effect of an increase in inhaled allergen dose after rimiterol hydrobromide on the occurrence and magnitude of the late asthmatic response and the associated change in nonspecific bronchial responsiveness. Am Rev Respir Dis 1989; 140:917-23.

5 O'Connor BJ, Aikman S, Barnes PJ. Tolerance to the nonbronchodilating effects of inhaled beta-2 agonists in asthma. $N$ Engl f Med 1992;327:1204-8.

6 Cockcroft D, McFarland C, Britto S, Swystun V, Rutherford B. Regular inhaled salbutamol and airway responsiveness to allergen. Lancet 1993;342:833-7.

7 Moreno RH, Hogg JC, Pare PD. Mechanics of airway narrowing. Am Rev Respir Dis 1986;133:1171-80.

8 Anderson SD, Smith CM, Rodwell LT, du Toit JI. The use of non-isotonic aerosols for evaluating bronchial hyperresponsiveness. In: Spector SL, ed. Provocative challenge procedures. New York: Marcel Dekker, 1993.

9 Pin I, Gibson PG, Kolendowicz R, Girgis-Gabardo A, Denburg JA, Hargreave FE, et al. Use of induced sputum cell counts to investigate airway inflammation in asthma Thorax 1992;47:25-9.

10 Woolcock AJ, Salome CM, Yan K. The shape of the doseresponse curve to histamine in asthmatic and normal subjects. Am Rev Respir Dis 1984;130:71-5.

11 Sterk P, Bel E. Bronchial hyperresponsiveness: the need for a distinction between hypersensitivity and excessive airway narrowing. Eur Respir f 1989;2:267-74.

12 Pepys J. Skin testing. Br f Hosp Med 1975;14:412-17.

$13 \mathrm{Bel} \mathrm{EH}$, van der Veen JH, Dijkman JH, Sterk PJ. The effect of inhaled budesonide on the maximal degree of airway narrowing to leukotriene D4 and methacholine in normal subjects in vivo. Am Rev Respir Dis 1989;139:427-31.

14 Peat JK, Unger WR, Combe D. Measuring change in logarithmic data, with special reference to bronchial responsiveness. F Clin Epidemiol 1994;47:1099-108.

15 Ramsdale EH, Morris MM, Roberts RS, Hargreave FE. Asymptomatic bronchial hyperresponsiveness in rhinitis. 7 Allergy Clin Immunol 1985;75:573-7.

16 Toelle BG, Peat JK, Salome CM, Mellis CM, Woolcock AJ. Toward a definition of asthma for epidemiology. $A m$ Rev Respir Dis 1992;146:633-7.

17 Chung $K$. The current debate concerning $\beta$ agonists in asthma: a review. $\mathcal{F} R$ Soc Med 1993;86:96-100.

18 Nijkamp F, Engels F, Henricks P, Van Oosterhout A. Mechanisms of $\beta$ adrenergic receptor regulation in lungs and its implications for physiological responses. Physiol Rev 1992;72:323-67.

19 Laitenen LA, Laitenen A, Haahtela T. A comparative study of the effects of an inhaled corticosteroid, budesonide, and a $\beta_{2}$ agonist, terbutaline, on airway inflammation in newly diagnosed asthma: a randomized, double-blind, parallel group controlled trial. f Allergy Clin Immunol 1992, 90:32-42.

20 Manolitsas ND, Wang J, Devalia JL, Trigg CJ, McAulay AE, Davies RJ. Regular albuterol, nedocromil sodium, and bronchial inflammation in asthma. Am $\mathcal{F}$ Respir Crit Care Med 1995;151:1925-30.

21 Hughes JM, Seale JP, Temple DM. Effect of fenoterol on immunological release of leukotrienes and histamine from human lung in vitro: selective antagonism by $\beta$-adhuman lung in vitro: selective antagonism by $\beta$-ad-

22 Larsson K, Martinsson A, Hjemdahl P. Influence of $\beta$ adrenergic receptor function during terbutaline treatment on allergen sensitivity and bronchodilator response to terbutaline in asthmatic subjects. Chest 1992;101:953-60.

23 Conolly M, Tashkin D, Hui K, Littner M, Wolfe R. Selective subsensitization of beta-adrenergic receptors in central airways of asthmatics and normal subjects during long term therapy with inhaled salbutamol. F Allergy Clin Immunol 1982;70:423-31.

24 van der Heidjen PJCM, van Amsterdam JGC, Zaagsma $J$. Desensitization of smooth muscle and mast cell $\beta$ adrenoreceptors in the airways of guinea pig. Eur f Respir Dis 1984;135:128-34.

25 Cockcroft DW, O'Byrne PM, Swystun VA, Bhagat R. Regular use of inhaled albuterol and the allergen-induced late asthmatic response. F Allergy Clin Immunol 1995;96:44-9. 